Ines Unetič

\title{
Botanični vrtovi in zbiranje rastlin v luči preobrazbe botaničnih zbirk na Kranjskem v začetku 19. stoletja
}

Ključne besede: botanični vrt, zbiranje rastlin, neavtohtone rastline, avtohtone rastline, baron Jožef Erberg, baron Žiga Zois, baron Karl Zois, jezuit Gabriel Gruber

DOI: $10.4312 /$ ars.9.2.60-83

Ob preučevanju vrtne umetnosti niso pomembni le vrtna zasnova, zgodovina oblikovanja vrtov, vrtni arhitekti in naročniki ali družbene spremembe, ki so narekovale nov vrtni slog, ampak je pomembno tudi, katere rastline so zanimale lastnike oblikovanih vrtov. Tako bomo tokrat pozornost usmerili na rastline, predvsem na nove in tuje rastlinske vrste, na njihovo zbiranje in zanimanje zanje konec 18. in na začetku 19. stoletja $v$ širšem evropskem prostoru, s poudarkom na Kranjskem. S pomočjo arhivskih virov - korespondenc, zapisov izdatkov, načrtov idr. - in takratnih strokovnih publikacij si bomo pobližje ogledali, kako so kranjski ustvarjalci in ljubitelji vrtne umetnosti v 18. in 19. stoletju spremljali in sprejemali nove rastlinske vrste. S primerjavo zbiranja rastlin v novem veku (do zgodnjega 19. stoletja) pa bomo odgovorili na vprašanje, kako se je dejavnost zbiranja rastlin prezentirala oz. kako so družbene spremembe vplivale na njeno preobrazbo.

Prvi danes znani podatki zbiranje rastlin umeščajo $\mathrm{v}$ čas starih civilizacij, $\mathrm{v}$ prostor Mezopotamije in Kitajske. Konec 12. stoletja pr. n. št. je bilo zbiranje eksotičnih rastlin in živali iz oddaljenih delov asirskega kraljestva in njihovo prenašanje $\mathrm{v}$ osrčje kraljestva oz. $\mathrm{v}$ prestolnico že izoblikovana praksa (pod vladavino kralja Tiglath-pileserja I.). Vladar Sargon II. je prek organiziranih velikih odprav za novimi rastlinskimi vrstami pridobil ogromno novih rastlin, ki so konec 8 . stoletja pr. n. št. polnile njegove velike botanične vrtove v mestu Sharroukin. V času vladarja Sennacheriba, sina Sargona II., so prav tako nastajali veličastni vrtovi, ki so jih redno polnili z novimi vrstami iz periferije in znotraj katerih je bil tudi botanični vrt (Amrhein, 2015, 92, 97; Bazin, 1990, 11). Sennacheribove vrtove bi lahko povezali z »veličastnim gozdom « (oz. Supreme Forest) kitajskega cesarja Wuja v drugem stoletju pr. n. št. (Amrhein, 2015, 98) ali z vrtovi prvega kitajskega cesarja Shi Huangdija, ki je 
v svojih vrtovih 221 pr. n. št. v bližini tedanjega glavnega mesta Xier Shanglina zbiral rastline in živali iz podrejenih dežel ter tudi tako demonstriral obseg svojega cesarstva (Rinaldi, 2010, 184).

Zbiranje tujih rastlinskih in živalskih vrst je izjemen pomen pridobilo $\mathrm{v} 16$. stoletju, v času radovednosti in kuriozitet. Tedaj so namreč nastali t. i. kabineti kuriozitet, katerih osnovno zanimanje je bilo usmerjeno $\mathrm{v}$ svet narave, čeprav bi lahko v njih našli najrazličnejše redkosti. Sčasoma so se ti kabineti vsebinsko bolj poenotili, tako bi lahko govorili o naravoslovnih kabinetih ter o kabinetih z antičnimi in drugimi umetninami. ${ }^{1}$ Naravoslovni oz. nekakšni vrtni kabineti so bili navadno sestavljeni iz različnih rastlin, kipov, grott z minerali ipd. (Hunt, 1986, 194). ${ }^{2}$ Glavno vodilo vseh kabinetov raritet je bilo, da so s svojimi zbirkami skušali poustvarjati celoten univerzum. Zbirke antičnih in umetniških del so ponazarjale teater spomina antične preteklosti, medtem ko so "vrtni kabineti« z zbirkami rastlin in živali ponazarjali teater celotnega sveta, izgubljenega $\mathrm{z}$ izgonom iz raja in ponovno pridobljenega s spretnostjo človekovih rok in uma (Hunt, 1986, 198). V primeru naravoslovnih kabinetov je sicer $\mathrm{z}$ vse večjim dotokom različnih tujih vrst to poustvarjanje raja postalo precej nepraktično. ${ }^{3}$ Tako ni nenavadno, da so v ospredje počasi stopile le nekatere rastlinske vrste, ki so postale posebno priljubljene med zbiratelji in so postale podobne artefaktom, ki so bili narejeni zgolj za kabinete, so bili v celoti delo človekovih rok in niso imeli uporabne vrednosti (Impey, MacGregor, 1986, 2). Med te (naravne) artefakte so v 16. in 17. stoletju sodili tulipani, ki so sprožili pravo tulipomanijo in so vplivali celo na tedanji ekonomski trg (Dash, 1999). Zanje so bili namreč posamezniki pripravljeni odšteti ogromne vsote - tako so na primer najvišjo ceno za gomolj, 5200 goldinarjev, zabeležili leta 1637 (Dash, 1999, 9). Kaj je pravzaprav predstavljala cena enega gomolja, lahko vidimo na primeru iz leta 1636

1 Naravoslovne zbirke so bile pogosto (predvsem v 17. stoletju) plod dela strokovnjakov oz. ljubiteljev, ki so svojo radovednost podkrepili z znanostjo. Laični in zgolj ljubiteljski zbiralci pa so se, če se niso želeli strokovneje ukvarjati $\mathrm{z}$ artefakti, pogosteje vrnili k zbiranju antičnih artefaktov in umetnin (Olmi, 1986, 11).

2 Na to specifikacijo prostorov, ki so zbiralcem (plemičem) širili obzorje, nakazuje tudi zapis Francisa Bacona s konca 16. stoletja: "First, the collecting of a most perfect and general library may be made contributory to your wisdom. Next, a spacious, wonderful garden, wherein whatsoever plant the sun of divers climate, or the earth our of divers moulds, either wild or by the culture of man brought forth, may be ... set and cherished: this garden to be built about with rooms to stable in all rare beasts and to cage in all rare birds... And so you may have in small compass a model of the universal nature made private. The third, a goodly, huge cabinet, wherein whatsoever the hand of man by exquisite art or engine has made rare in stuff, form or motion... The fourth such a still-house, so furnished with mills, instruments, furnaces, and vessels as may be palace fit for philosopher's stone. "Podani zapis iz Gesta Grayorum (1594) je objavljen v Impey, MacGregor, 1986, 1.

3 Podatki, ki jih poda John Dixton Hunt v prispevku iz leta 1986, nakažejo to povečevanje števila rastlin v Veliki Britaniji. Kot primer navede Tradescantov vrt v Lambethu, ki je bil znan po velikem naboru divjih avtohtonih in uvoženih rastlin. Leta 1634 je nastal katalog rastlin v tem vrtu - teh je bilo okoli 750. Do leta 1656 pa se je njihovo število več kot podvojilo (Hunt, 1986, 201). 
- čebulice tulipana, ocenjene na tri tisoč goldinarjev. Za to vsoto bi posameznik v tistem času dobil: osem debelih prašičev, štiri dobro rejene vole, dvanajst debelih ovc, štiriindvajset ton pšenice, oseminštirideset ton rži, dva 300-litrska soda vina, štiri sode piva, dve toni masla, pol tone sira, srebrno čašo za pitje, zavoj oblačil, posteljo z žimnico in posteljnino ter ladjo (Dash, 1999, 254-255). ${ }^{4}$

V 18. stoletju pa je prišlo do sprememb, ki so se odražale tudi v zbiranju rastlin. $\mathrm{V}$ tem stoletju so se namreč pojavile $\mathrm{z}$ razsvetljenstvom pogojene spremembe in novosti na različnih področjih - tako v industriji kot $\mathrm{v}$ znanosti. Posledično se je spremenilo tudi dojemanje naravnega okolja, kar je bilo med drugim vezano na razvoj in napredek $v$ gospodarstvu. Vse to je rezultiralo $v$ jasno časovno delitev dela in pojav prostega časa ter z njim povezanega turizma. Družba je začela ceniti krajino in obiskovati kraje, kjer se je lahko razgledovala po zelenem prostoru. Na drugi strani je bil spremenjen estetski okus, ki se je v marsičem opiral na novoodkrite antične spise in reakcije nanje, ki so vodile $\mathrm{v}$ razširjeno idejo sublimnega. Tako začne družba ceniti veličastne naravne pojave ter nov vrtni slog, ki je vključeval različne naravne »scene« z umetniškimi artefakti, namenjene vzbujanju različnih občutij. Narava ni bila več vseobsežni kozmos, zgrajen po načelu pravilnih razmerij, ampak doživljajski prostor človeka in prostor Božje ustvarjalnosti (Parsons, 2008, 1-17; Düselder, 2008, 32). Rastlina kot del narave je tedaj pridobila drugačen poudarek in obravnavo, ki se je izrazila v vse večjem pomenu botanike. Botanika je v 18. stoletju postala znanstvena $v^{2} \mathrm{a}^{5}$ in posledično so se tudi zbiratelji rastlin $\mathrm{z}$ njimi strokovno ukvarjali. Zanimanje za rastline - tako avtohtone kot neavtohtone - je postalo strast raziskovalcev, intelektualcev in vladarjev. Angleški dvor je Jurij III. okronal s kraljevim botaničnim vrtom Kew Gardens (ustanovljenim leta 1760), francoski dvor je z novimi rastlinami bogatil kralj Ludvik XVI., zelo dejavna pa je bila tudi prva žena Napoleona I., cesarica Joséphine de Beauharnais. Nemški vladarji so prav tako ustvarjali svoje botanične zbirke - nadvojvoda Carl August von Sachsen-Weimar in saški kralj Friedrich August I. der Gerechte (Pravični) sta imela celo osebni botanični kabinet, v katerem sta lahko preučevala botanične novosti. Za naš prostor je gotovo najpomembnejši avstrijski kralj Franc I., ki je imel svoj botanični vrt v Schönbrunnu - ta je veljal celo za drugega

4 V 17. stoletju je na Kranjskem v svojem vrtu na Lisičju zbiral tulipane Merharič oziroma Fabijanič (Leonard Merharitsch genannt Fabianitsch). Imena njegovih tulipanov nam je ohranil Valvasor v svoji Slavi vojvodine Kranjske, našteti so npr. Apollo, Aurora Celeste, Bella Diana, Bella Helena, torej sama visoko zveneča imena - imena generalov, kardinalov, krajev, mitoloških junakov in božanstev (Valvasor, 1689, XI/172-178). Natančneje se je z vrstami tulipanov v Lisičju ukvarjal Marko Dobrilovič v svojem članku (Dobrilovič, 2009).

5 O velikem napredku v tej disciplini priča delo Carla Linnaeusa (1707-1787) - predvsem njegova nomenklatura, ki jo uporabljamo še danes. Carl von Linné, kot nam je danes bolj znan in si je ta priimek nadel leta 1762, ko je bil povišan v plemstvo, je že leta $1730 \mathrm{v}$ katalogu Hortus uplandicus prvi prikazal sistemsko razdelitev flore po novem seksualnem sistemu. Pri poimenovanju vrst se je držal binomskega načela (na primer Homo sapiens) in tako do leta 1753 poimenoval približno 7700 rastlinskih in 4400 živalskih vrst (Linné, 1995, 51, 52; Scopoli, Linné, 2004, 24-27, 30, 32, 33, 36). 
največjega v Evropi (takoj za angleškim Kew Gardens). ${ }^{6}$ Zbiranje rastlin je postalo prava dvorna in nato še vsesplošna moda, ki pa so jo v veliki meri narekovali Angleži - kraljevi Kew Gardens v Veliki Britaniji je imel zaposlenih več lovcev na rastline, ki so pošiljali primerke $\mathrm{z}$ vseh koncev sveta, na ta način pa se je botanični vrt uspešno širil (Symes, 1993, 92-93). ${ }^{7}$ Če si torej želel biti v koraku s časom, si moral slediti angleškemu dvoru ali drugim večjim zbirateljem - tega dejstva se je zavedal tudi avstrijski vladar, ki je od svojega dvornega vrtnarja Franza Antoina zahteval, da je poznal vse nove vrste, ki so prišle v kraljestvo, ${ }^{8}$ in jih uvajal v dvorne vrtove ter tako ohranjal sloves drugega največjega botaničnega vrta $\mathrm{v}$ Evropi.

Tovrstni dvorni primeri so bili jasen zgled za vse, ki so želeli biti v koraku s časom in ki so hoteli pokazati na svoj pomemben položaj v družbi oziroma nakazati svojo ambicioznost. Na Kranjskem je to modno botanično navdušenje zajelo barona Jožefa Erberga, barona Žiga in Karla Zoisa, Riharda Ursinija grofa Blagaja, jezuita Gabriela Gruberja, stolnega kanonika Weberna in mnoge druge.

Baron Jožef Erberg (1771-1843)9 je lahko kraljevo zanimanje za botaniko in vrtno umetnost od blizu spoznal, ko je v letih 1809-1814 služboval na Dunaju. Dvorno okolje je vplivalo na njegovo delovanje na Kranjskem, na kar nakazuje tudi urejanje velikega oblikovanega vrta v Dolu pri Ljubljani. Velikopotezno ga je začel urejati takoj po vrnitvi v deželo, vanj je vnašal novosti v oblikovanju in rastlinah, sledil pa je tudi nemškim zgledom pri izobraževanju vrtnarjev (Unetič, 2013, 124132). Na pomembnost, ki jo je vrtna umetnost odigrala v baronovem življenju, kažejo arhivski viri - predvsem korespondenca. Baron je namreč s svojimi pismi povezoval strokovnjake in ljubitelje rastlin ter vrtne umetnosti. S pomočjo pisem lahko izvemo, kdo se je zanimal za novopridobljene rastline $\mathrm{v}$ dolskem vrtu, katere rastline so bile posebno priljubljene ali kje je baron naročal rastline - kot je z nekaj primeri predstavljeno v nadaljevanju.

6 O vsesplošnem botaničnem zanimanju dvora glej v Pfundheller, 1881; Baumgartner, 2001, 182, 183; Lack, 2006, 12, 19, 23, 28; Melzer, 2007/2008, 120-122, 124, 126; Melzer 2008, 357, 364. V članku avtorice pričujočega prispevka, ki bo objavljen v okviru zbornika simpozija Arhitekturna zgodovina iz leta 2014, pa je ponazorjeno tudi prevzemanje te nove mode znotraj kranjskega plemstva.

7 Pri tem lahko opazimo kolonialno težnjo Velike Britanije oz. ponovitev zbirateljstva, kot so ga poznali asirski in kitajski vladarji v starem veku.

8 Ob tem je treba omeniti, da je moral biti Antoine pozoren predvsem na zbirko grofa Harracha, ki je v kraljestvu veljal za najboljšega poznavalca rož (Pfundheller, 1881, 10).

9 Jožef je pripadal družini Erberg, ki je na Kranjskem omenjena že v 16. stoletju. Leta 1789 je prevzel posest Dol pri Ljubljani, leta 1794 pa se je poročil z Jožefino Katarino grofico Attems (1778-1847) iz Podgore pri Gorici. Jožef je leta 1804 dobil naziv komornika, v času 1805-1806 je bil član provizorične deželne uprave, od 1795 do 1808 stanovski poverjenik, od 1809 do 1814 pa vzgojitelj prestolonaslednika Ferdinanda. Kot on je tudi njegova žena delala na Dunaju, saj je že leta 1808 postala vzgojiteljica cesarskih otrok. Jožef je bil ljubitelj umetnosti in tudi sam amaterski slikar (Mušič, 1961, 93; Umek, 1991, 13, 17; Ferjan, 2002, 263). 
$\mathrm{V}$ dolskem vrtu so imele pomembno mesto pelargonije. Te danes značilne balkonske rastline so bile bolj grmičaste rasti (dosegle so do $80 \mathrm{oz} .150$ centimetrov višine) in skromnih cvetov. Pelargonije so v Evropo iz svojih kolonij v Južni Afriki prinesli Nizozemci nekako po letu $1653 .{ }^{10}$ Baron Erberg je imel v dolskem vrtu pelargonije v večjem številu leta $1813,{ }^{11}$ so pa v Dolu verjetno uspevale že od konca 18. stoletja. Iz pisma stolnega kanonika Weberna ${ }^{12}$ iz Ljubljane (20. maja 1797) namreč izvemo, da je kanonik baronu ponudil korenine pelargonij, ki mu jih je posredoval Franc Anton Breckerfeld ${ }^{13}$ (SI AS 730, fasc. 55, fol. 697). Baron Erberg je tako pridobil pelargonije prek drugih ljubiteljev tujih rastlin, številne pa je tudi kupil. Nakup je lahko opravil kar v Ljubljani pri mestnem vrtnarskem mojstru Josephu Schultzu (SI AS 730, fasc. 23, fol. 5901) ali pa v tujini, najpogosteje na Dunaju, od koder mu jih je pošiljal gospod Walser (SI AS 730, fasc. 55, fol. 588). Baronovo navdušenje nad to rastlinsko vrsto je dokazovala slika 50 Lustallern Pelargonien in einem bouquet auf einen grosten velin Zorgen ..., katere obstoj nakazuje dolski arhiv in ki jo je baron najverjetneje sam izdelal (najkasneje leta 1826; SI AS 730, fasc. 76, seznam risb). O posebnem zanimanju za to rastlino govori še en arhivski zapis, namreč o knjigi Pelargonia in Horto Lustalensi (SI AS 730, fasc. 23, fol. 5989), ki bi lahko služila kot nekakšen katalog vseh vrst pelargonij v Dolu oz. kot prodajni katalog za pelargonije. Tovrstni katalogi so drugim ljubiteljem, laikom in strokovnjakom, omogočali, da spoznajo rastlinsko bogastvo določenega lastnika ter pridobijo zase tiste rastline, ki so se jim zdele zanimive oz. aktualne. ${ }^{14}$

10 V Evropi lahko prve vrste zasledimo že leta $1632 \mathrm{v}$ južnem Londonu. Že konec 18. stoletja so sicer začeli spreminjati podobo same rastline, saj so žlahtnitelji postopoma spreminjali vrsto oziroma sorte pelargonij. Minilo je kar nekaj časa, da so ustvarili nižje (pritlikave) rastline in tako barvite, kakršne poznamo danes (Steffen, 1940, 380; Möhring, 1952, 190; Reiter, 1952, 60; Rupprecht, Miessner, 1985, 499, 500, 502-506; Riedl-Dorn, 2001, 200; Wilkinson, 2007, 13-14, 21-24; Bartha-Pichler, 2010, 108).

11 Tega leta je namreč dolski vrtnar (17. februarja 1813) baronu poročal o stanju v vrtu in omenil, da različne vrste pelargonij že lepo rastejo in snujejo cvetove (SI AS 730, fasc. 55, fol. 812).

12 Stolni kanonik Webern v korespondenci ni omenjen s celim imenom, a predvidevamo lahko, da gre za Frančiška Ksaverja Antona de Weberna (1743-1816), kanonika Wolwizove ustanove (Zgodovinski zbornik, 2013).

13 Breckerfeld (1740-1806) je bil znan zbiratelj leksikalnega in narodnega gradiva ter pisec historičnotopografskih črtic za nekatere kraje in gradove Dolenjske; opisal je tudi razmere v Istri, ko je bil polnomočni komisar v pazinski grofiji itn. (Mal, 1925-1932, 57). Njegovo rokopisno gradivo se je ohranilo v graščinskem arhivskem fondu Dola pri Ljubljani.

14 Baron Erberg je imel še številne druge rastline. Med zanimivejšimi so bili sukulenti, predvsem agave (Unetič, 2013, 144-146). 


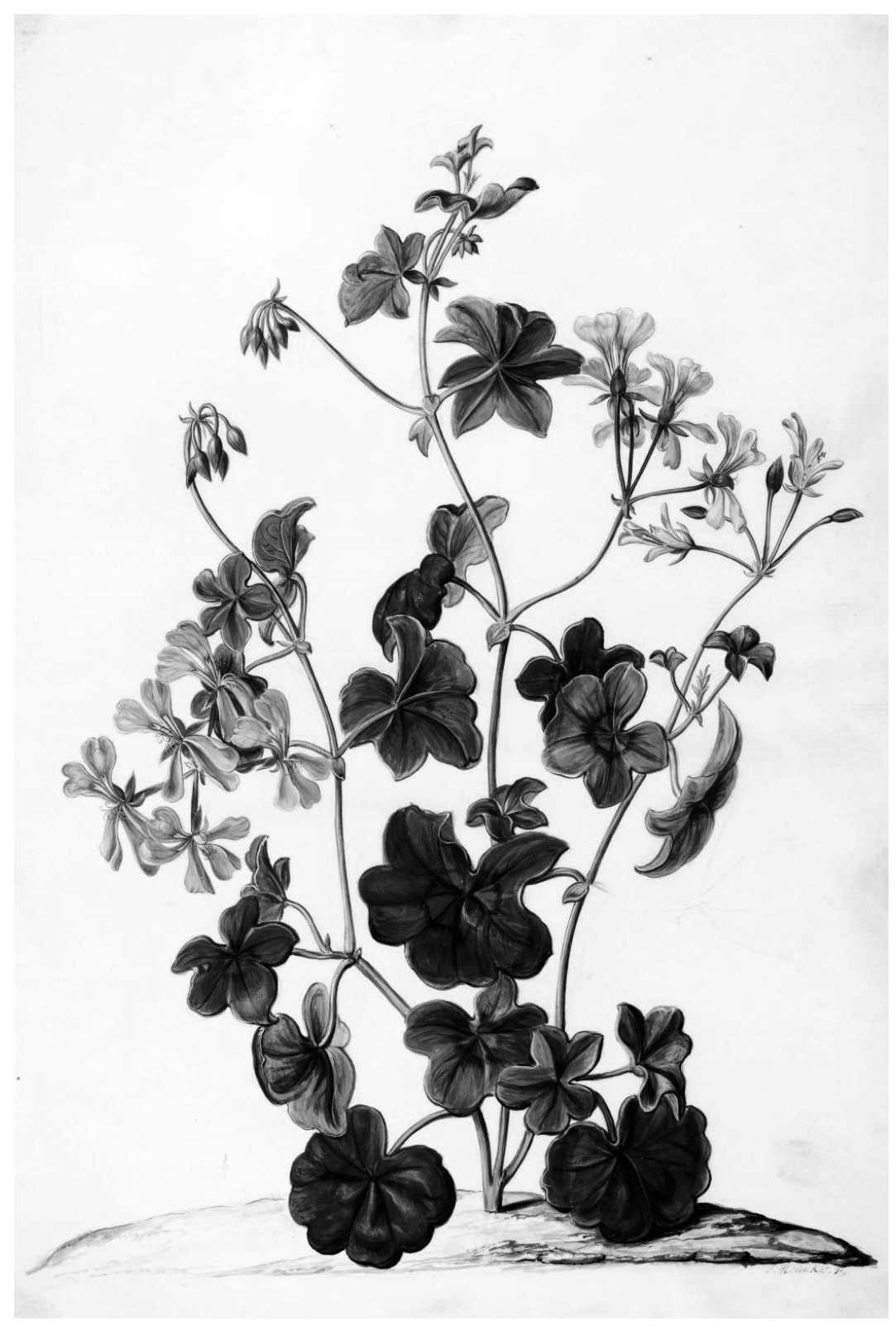

Slika 1: Izvorna vrsta današnjih hibridov je Pelargonium peltatum, ki naj bi se že okoli leta 1701 pojavila na Nizozemskem. Vrste, ki izhajajo iz nje, danes uvrščamo v skupino bršljanastih pelargonij (Pelargonium peltatum). 


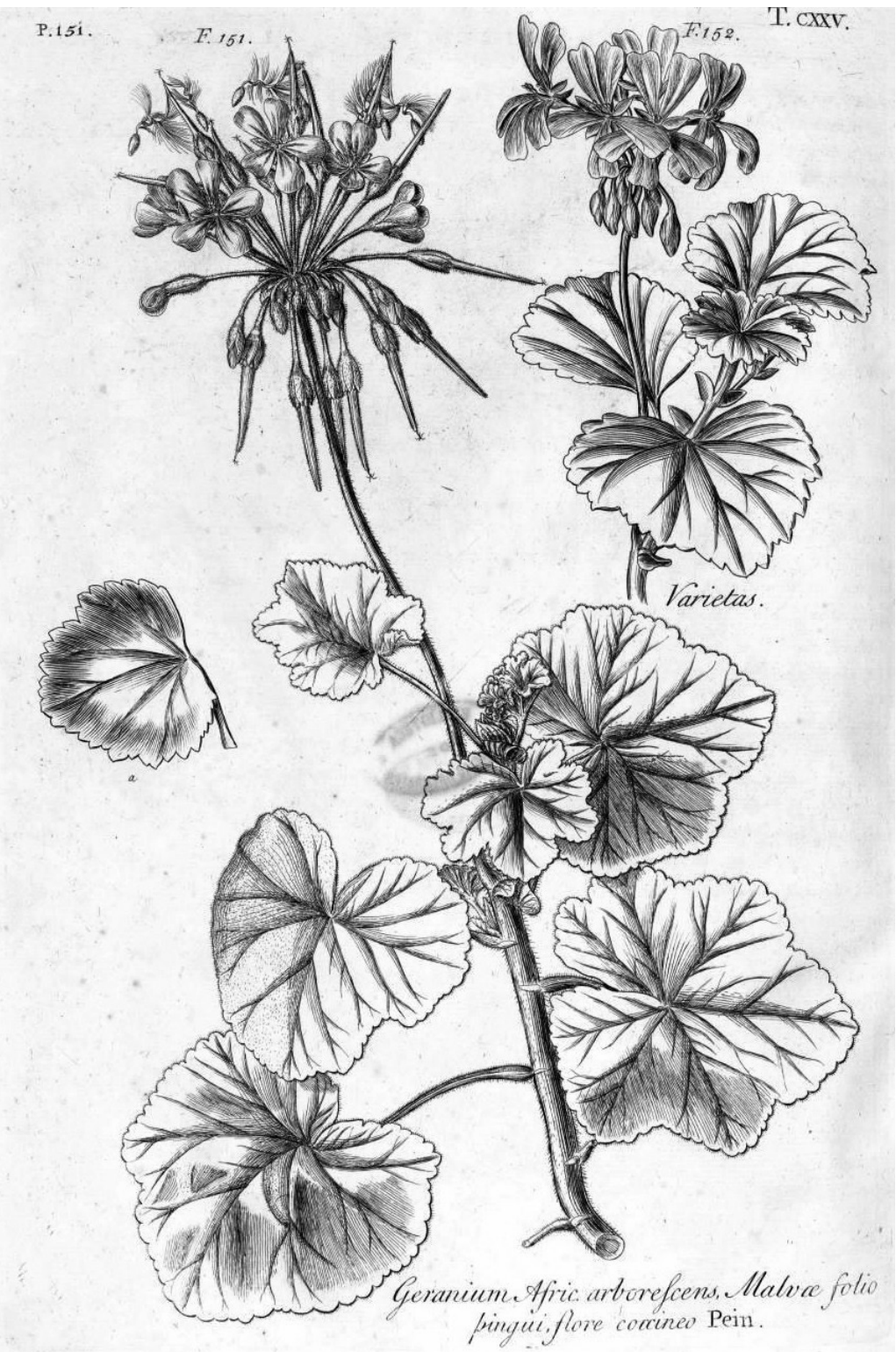

Slika 2: Druga, za današnje križance pomembna vrsta je bila Pelargonium inquinans, ki je leta $1714 \mathrm{z}$ Rta dobrega upanja prišla v Anglijo (hibridom je dala sijočo škrlatno barvo). Po drugih podatkih naj bi prišla v Evropo konec 18. stoletja, in sicer prek znanega lovca na rastline Massona. Vrsta je bolj grmičaste rasti in je $\mathrm{v}$ višino dosegla tudi 1,50 metra. Ilustracija je bila objavljena v knjigi Johanna Jacoba Dillena Dilleniusa Hortus Elthamensis iz leta 1732 (Pelargonium inquinans). 
Posebno mesto v dolskem vrtu so imele tudi agave oz., kot so jih tedaj imenovali, aloe. ${ }^{15}$ Agave so iz novega sveta v Evropo prišle že v zgodnjem 16. stoletju in so kmalu postale prestižni element oblikovanih vrtov. ${ }^{16}$ Izjemno zanimanje so vzbujale zaradi svojega cvetenja, saj je večina vrst agav monokarpičnih, kar pomeni, da cvetijo le enkrat v življenju. ${ }^{17}$ Tako ni bilo nenavadno, da so ponosni lastniki radi poročali o cvetenju agav v svojih vrtovih. ${ }^{18}$ Tudi baron Erberg je sodil mednje, saj je pozorno spremljal rast svojih agav. Kot lahko razberemo iz arhivskih virov, so imeli v Dolu vsaj tri agave: prva je leta 1809 pripravljala cvetove, a je podlegla glinobi, druga je leta $1812 \mathrm{v}$ cvetu potovala $\mathrm{v}$ Eisenstadt, tretja pa je cvetela $\mathrm{v}$ začetku tridesetih let 19. stoletja. Predvsem v primeru druge dolske agave lahko vidimo, kakšen pomen je imela ta rastlina za zbiratelje ter kako razširjena in priljubljena je bila tedaj moda zbiranja tujih rastlin. Baron Erberg je v času, ko so v Dolu opazili, da agava pripravlja cvetno steblo, še služboval na Dunaju. Deloval je torej v okolju drugih plemičev, zbirateljev in ljubiteljev vrtne umetnosti in je novico o skoraj cvetoči dolski agavi sporočil tudi Nikolaju II. knezu Esterhazyju (1765-1833), znanemu zbiratelju in lastniku izjemnega oblikovanega vrta v Eisenstadtu, ki naj bi po velikosti in bogastvu botanične zbirke tesno sledil vladarjevemu Schönbrunnu (Prost, 2001, 44-47; Galavics, 2001, 120121). Knez Esterhazy se je nad dolsko agavo navdušil in se z Erbergom dogovoril o izmenjavi rastlin. Agavo naj bi prepeljali v njegov vrt v Eisenstadt, v zameno pa naj bi knez dal štirideset različnih rastlin iz svojega vrta. Baron Erberg je s pomočjo inšpektorja dolske posesti, dr. Jožeta Lusnerja, in dolskega vrtnarja Jožeta Bohinca (oz. Wochinza) v drugi polovici leta 1812 organiziral dolgo pot agave, ki je bila $\mathrm{v}$ času cvetenja (cvetno steblo je doseglo izjemno višino - približno sedem metrov in pol) s posebnim vozom prepeljana v domovanje novega ponosnega lastnika. ${ }^{19}$ Tudi o tretji dolski agavi se je razširil glas, a na nekoliko drugačen način. O njej je v bavarskem časopisu Allgemeine deutsche Gartenzeitung leta 1833 poročal dolski vrtnar Georg Bauer. Bauer je v tem prispevku opisal cvetenje te že več kot štirideset let stare agave, ki je cretela kar šest mesecev (čez poletje 1832), prav tako pa je ohranil njeno podobo, saj je bila v okviru tega članka tudi litografija (Bauer, 1833). Izjemnost rastline je privabila številne obiskovalce, ki so prihajali v dolski vrt in si jo ogledovali - za lažje opazovanje

15 Taksonomija v tistem času še ni bila poenotena in dodelana, zato je bilo poimenovanje rastlin iz rodov Agava, Yucca in Furcraea pogosto poenostavljeno s poimenovanjem aloe.

16 Bauer, 1833, 265; Teichert, 1991, 201; Irish, Irish, 2000, 49-50; Heller, 2003, 6.

17 Agave americana $\mathrm{v}$ toplem podnebju navadno cveti po 10 letih, $\mathrm{v}$ mrzlih podnebjih pa potrebuje 35 let ali več (Irish, Irish, 2000, 26, 96).

18 Leta 1627 je Agave americana cvetela v dvornem vrtu v Anspahu, leta 1634 v Münchnu, leta 1658 pa je zacvetela vsaj 75 let stara agava v Stuttgartu (12.000 cvetov). Leta 1662 je cvetela agava v Glogauu, 1665 je cvetela 56 let stara agava v Khori v Meissnu (3000 cvetov), okoli leta 1668 je omenjena rastlina cvetela v Gottorfu, 1700 v Leipzigu, 1713 v Arnstadtu, leta 1782 pa v vrtu mestne lekarne v Hamburgu (Teichert, 1991, 125, 140, 157, 178, 180, 183, 204, 205, 206, 210, 211).

19 Za natančnejši opis dogodkov glej Unetič, 2013, 144 s tam navedenimi arhivskimi viri in literaturo. 
so jo postavili celo na oder. ${ }^{20} \mathrm{O}$ velikem obisku dolskega vrta $\mathrm{v}$ tem času poroča Betty oz. Elise Erberg 26. junija 1832 v pismu bratu Jožefu Ferdinandu Erbergu, v katerem zapiše, da prihaja veliko ljudi v Dol gledat aloe in da je bilo na velikonočni ponedeljek v Dolu štiriindvajset vozov. ${ }^{21}$

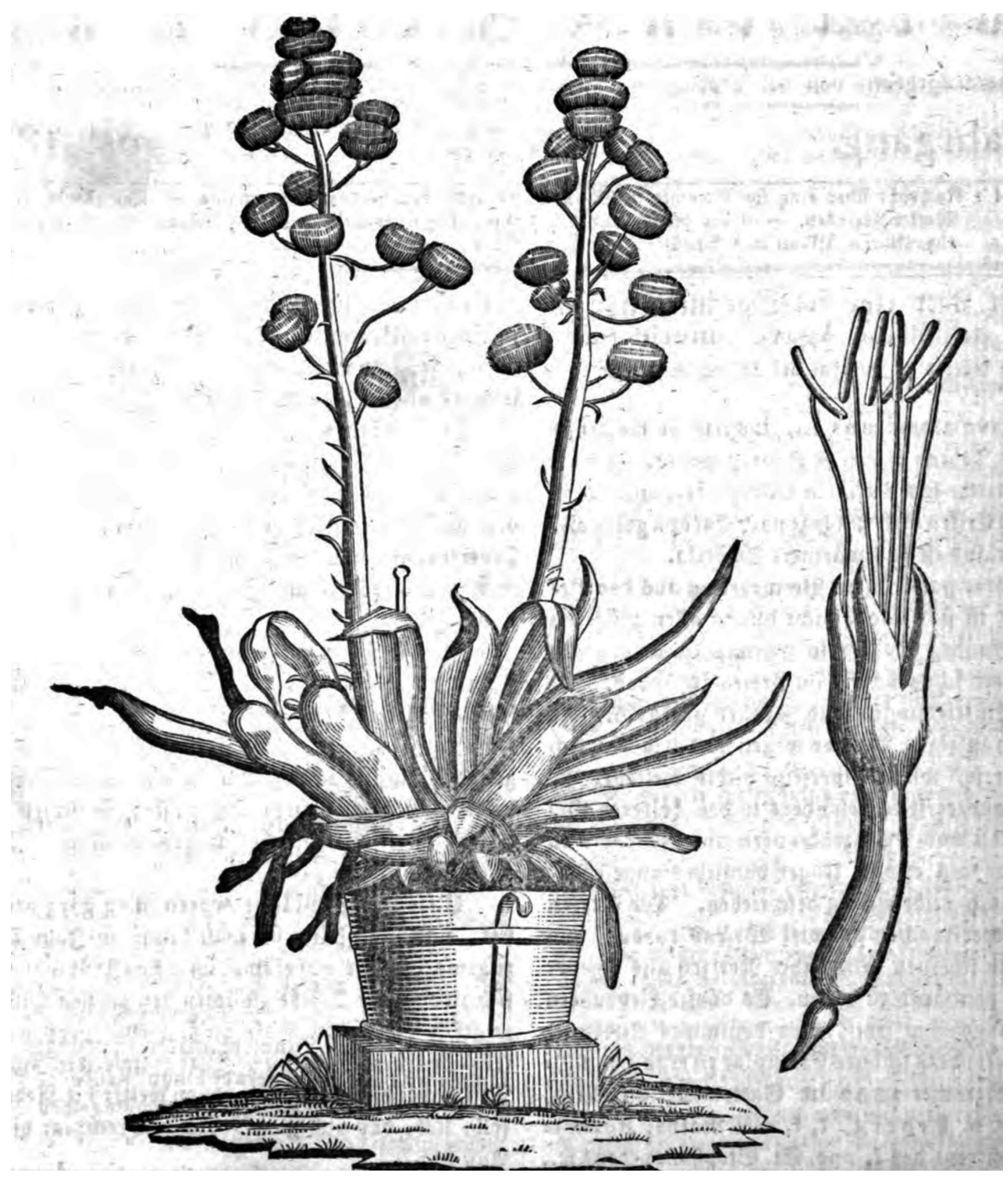

Slika 3: Upodobitev leta 1832 cvetoče dolske agave v bavarskem vrtnem časopisu (Bauer, 1833, 266).

20 Glej tudi Unetič, 2013, 145.

21 "... Heuer kommen viele Leute nach Lustahl, um die Aloe, die fruer blöhen wird zu sehen, am Pfingstmontag, waren 24 Wägen hier, und so geht es beinahe alle Feiertage« (SI AS 730, fasc. 63). 


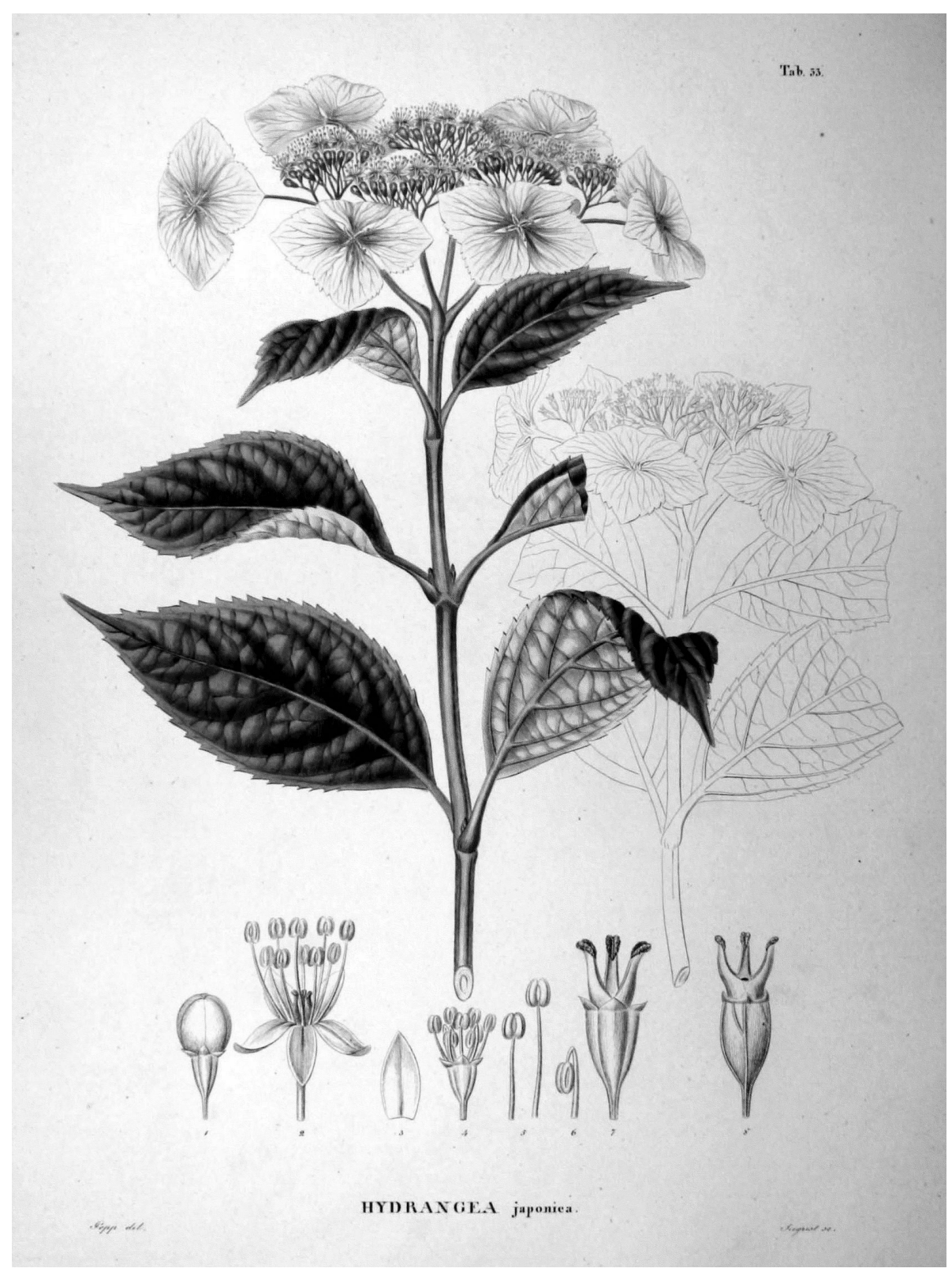

Slika 4: Velikocvetna hortenzija, kot sta jo upodobila Philipp Franz von Siebold in Joseph Gerhard Zuccarini v Flora Japonica iz leta 1870

(Hydrangea macrophylla). 
Med obsežnim rastlinskim bogastvom v Dolu je baron Erberg imel tudi hortenzije, saj arhivski viri poročajo, da so februarja 1813 že dobro poganjale (SI AS 730, fasc. 55 , fol. 812), leta 1816 pa so že tako dobro uspevale, da je dolski vrtnar avgusta lahko prodal majhno hortenzijo za 45 krajcarjev (SI AS 730, fasc. 20, fol. 97). Hortenzije so bile nekaj povsem novega, saj so jih šele leta $1788 \mathrm{iz} \mathrm{Japonske} \mathrm{prinesli} \mathrm{v} \mathrm{Evropo}$ (Reiter, 1952, 53; Rupprecht, Miessner, 1985, 298-299, 305, 395; Bartha-Pichler, 2010, 100-101). Zaradi bogatega in dolgo obstojnega cveta so bile še posebno zanimive in nadvse priljubljene - tako ni nenavadno, da so vzbudile zanimanje še enega kranjskega ljubitelja rastlin, barona Žiga Zoisa. Cvet hortenzije pa je bil tisti, ki je Zoisa najbolj navdušil, kot je v pismu baronu Erbergu poročal 10. oktobra 1808. Baron Erberg mu je namreč posodil hortenzijo, za kar se v pismu zahvaljuje, med drugim pa je v pismu omenil tudi risbo Laxenburga $v$ jeseni s prizorom tristotih hortenzij na enem mestu, ki jo je prav tako dobil od Erberga (tudi to risbo je baron Jožef Erberg verjetno izdelal sam; SI AS 730, fasc. 75, fol. 1039). Žiga Zois si je torej hortenzijo iz Dola sposodil ali dobil na posodo nekako na začetku leta 1808 ali že leta 1807, a ga je tako prevzela, da jo julija 1808, ko je k njemu prišel dolski vrtnar z novimi rastlinami iz Dola, še ni vrnil (oz. hotel vrniti; SI AS 730, fasc. 39, fol. 68). Namreč »die Hortenzia wil b: Zois noch nicht zurikgäben solang eine blume zu sehen «, cvet pa je vztrajal očitno vse do novembra, ko se je hortenzija le vrnila v Dol (SI AS 730, fasc. 23, fol. 6426). Erberg je tako moral prepoznati veliko Zoisovo zanimanje za to rastlino in mu je predvidoma konec leta 1809 poslal šest hortenzij v stalno rabo (SI AS 730, fasc. 75, fol. 1061).

Nove rastline niso prevzele le plemičev, trgovcev, vrtnarjev in drugih posvetnih mož. Kot smo lahko videli, se je za pelargonije zanimal stolni kanonik, pa tudi jezuit Gabriel Gruber je imel v svojem domu prostor za cvetlični okras. Čeprav je bival v majhnem mestnem stanovanju, je okenske police napolnil z različnimi čebulnicami, kot so bili avriklji (rod: primula), ki so v Evropo prišli večinoma iz azijskega ali južnoameriškega sveta, ter vetrnicami (rod: anemone), ki uspevajo v blagi klimi (SI AS 730, fasc. 43). Gruber je pridobil rastline tako iz Dola kot iz Brda pri Kranju, pa tudi kanonik Webern mu je prinesel kakšno. Patra so rastline nadvse zanimale (ali pa je le rad obiskoval domače plemstvo), saj je baronu Erbergu v njegovi odsotnosti leta 1796 poročal o neurju, ki je povzročilo škodo v dolskem vrtu, in o svojem namenu, da bo vrtnarja baronov Zois v Brdu pri Kranju presenetil z nenapovedanim obiskom, da vidi, kako skrbi za rastline, ki so mu bile zaupane (SI AS 730, fasc. 43). 


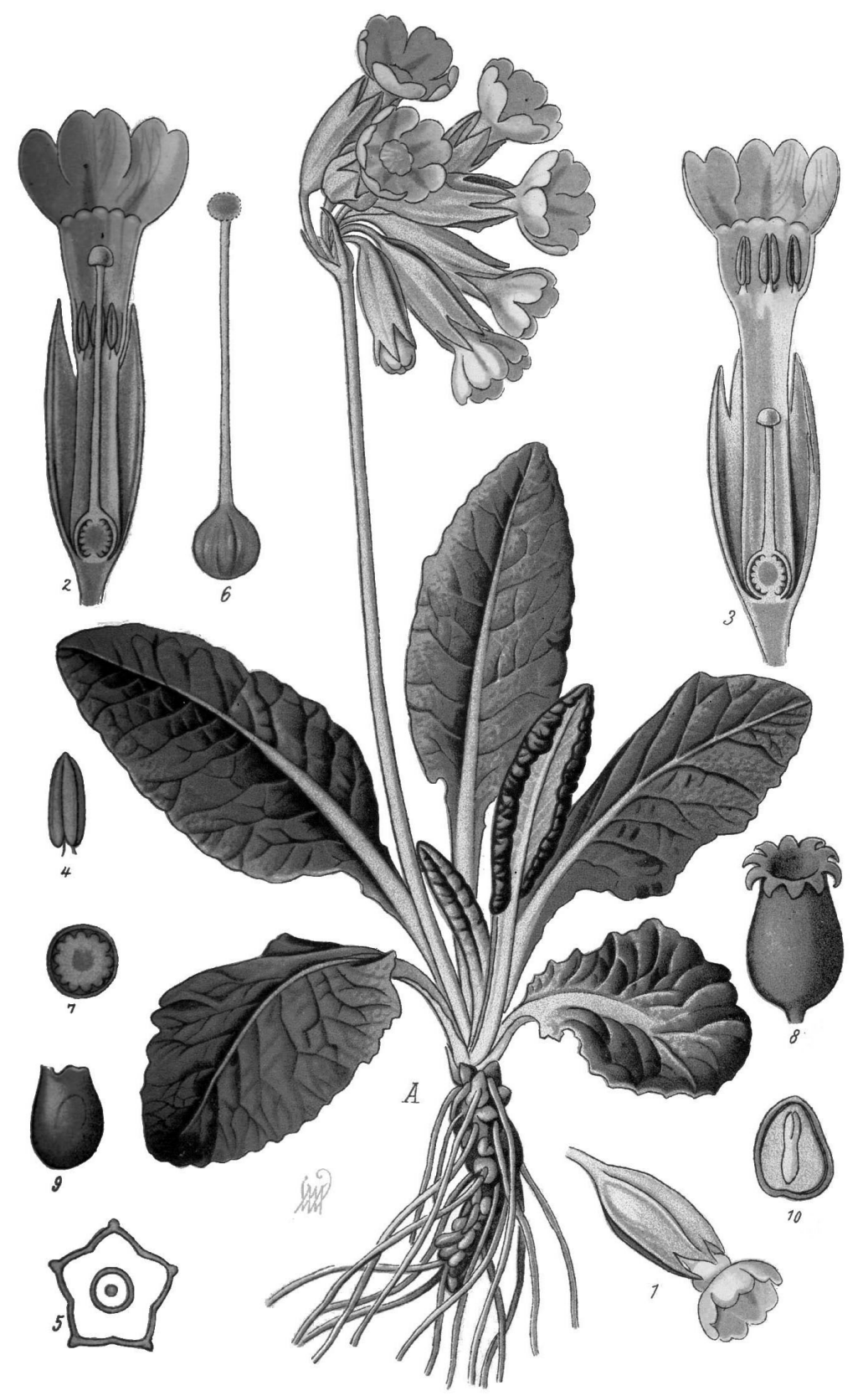

Slika 5: Primula iz knjige prof. dr. Otta Wilhelma Thoméja Flora von Deutschland, Österreich und der Schweiz iz leta 1885 (Primula veris). 
Rastlinsko bogastvo so v 18. in zgodnjem 19. stoletju zbirali na različne načine posušene primerke so shranjevali v herbarijih ali pa so dali izdelati ilustracije posameznih rastlin, ki so bile nato shranjene v zbirkah, kot na primer t. i. Florilegien avstrijskega kralja Franca I.22 Najbolj priljubljene pa so bile seveda zbirke na prostem rastočih rastlin, a je moral lastnik zbirke imeti dovolj prostora in finančnih sredstev, da je lahko uredil površino $\mathrm{v}$ vrtu in rastlinjake za svoje botanične primerke oz. da je lahko uredil »botanični vrt«. ${ }^{23}$ Takšen botanični vrt so na Kranjskem imeli barona Zois in baron Erberg. Brata Zois sta ustvarila prvi botanični vrt na Kranjskem (na Brdu pri Kranju) ter prvi botanični vrt v Ljubljani (Dobrilovič, Kravanja, 2003, 279, 284-285; Praprotnik, 2004, 168; Unetič, 2013, 81, 82, 98, 101, 191). Brata Zois sta si pri snovanju svojega botaničnega vrta najverjetneje pomagala s knjigo Beiträge zur schönen Gartenkunst iz leta 1783, ki sta jo imela v svoji knjižnici in ki je med drugim vsebovala napotke za ureditev botaničnih vrtov (Medicus, 1783). Avtor knjige poudarja, da botanični vrt ne sme biti zbirka raritet in ne sme postati "... ein solches zusammen Gestoppeltes Ding ... " (Medicus, $1783,126)$, kar se kaj hitro zgodi, saj je bila takratna navada urejanja botaničnih vrtov $\mathrm{v}$ številnih mestih in krajih - vsaj po Medicusovem mnenju -, da so vrt napolnili z rastlinami, ki so bile pri roki, tako pa ustvarili nekakšno, kot že rečeno, skupaj nametano stvar, za katero se je zdelo, da je nastala samo zato, da se lahko njen lastnik pohvali z lastnim botaničnim vrtom (Medicus, 1783, 126-127, 129). Kakšna je bila predlagana zasnova oziroma členitev botaničnega vrta, iz danih opisov ni mogoče razbrati, zelo verjetno pa je bil botanični vrt členjen na manjše pravilne ploskve, ki so omogočale lažjo nego in dostop do rastlin. Tovrstno shemo lahko v večji ali manjši meri prepoznamo na Brdu pri Kranju in v Dolu pri Ljubljani. Botanični vrt na Brdu pri Kranju je bil urejen na mestu nekdanjega baročnega parterja - sledil je formalni zasnovi in je bil neposredno ob vrtni fasadi dvorca. ${ }^{24} \mathrm{~V}$ njem so bile zbrane različne, večinoma avtohtone rastline, a kljub njihovi predvidoma sistematični razporeditvi je struktura zasaditve ustvarjala vtis prijetnega in intimnega zelenega prostora. Kakšna je bila zasnova Zoisovih vrtov v Ljubljani, katerih del je bil tudi botanični vrt, ni jasno. Gotovo je bila shema formalna, a zdi se, da so bile rastline bolj neenakomerno razporejene po prostoru, tako da so obiskovalce izobraževale v bolj neformalnem duhu. Tudi v dolskem vrtu je bil Arboret oziroma botanični prostor, ki se je nahajal na robu formalnega, reprezentativnega

22 Ilustracije so deloma objavljene v: Lack, 2006, 47-288.

23 Besedna zveza botanični vrt je v narekovajih, saj v tem času lastniki zbirk še niso sistematično urejali delov vrtov, v katerih so predstavljali svoje botanične zaklade. V večini primerov iz tega časa torej še ne moremo govoriti o botaničnem vrtu, kot ga poznamo danes.

24 Ta vrt je imel štiri vrtna vrata, razdeljen je bil na 24 enakomerno in simetrično razmeščenih pravokotnih polj, bil pa je na dveh nivojih (z višinsko razliko $60 \mathrm{~cm}$ ). Zunanje robove polj so zamejevali sadni špalirji, nekaj časa celo špalir iz božjega drevesca, v poljih so bile razporejene najrazličnejše rastline - trajnice $\mathrm{v}$ pasovih, grmovnice, jagodičje, vzpenjavke v nizkih špalirjih, rastline v posodah, oblikovano sadno drevje itn. (Petkovšek, 1960, 11-23; Dobrilovič, Kravanja, 2003, 227-286; Praprotnik, 2004, 167-174; Unetič, 2013, 233). 
dolskega vrta. Ta prostor je vseboval predvsem tuje drevesne vrste, ki so bile razporejene v pravilnem rastru, a so med njimi vodile krožno oz. segmentno nanizane poti, rastline v njem pa so bile označene s posebnimi imenskimi tablicami. ${ }^{25} \mathrm{Zdi}$ se, da kranjski ljubitelji in zbiralci rastlin svojih botaničnih vrtov niso oblikovali po enotni shemi. Baronu Karlu Zoisu, ki je urejal domači botanični vrt, je bila bližje formalna, pravilna in simetrična struktura, pripravna za sistematično preučevanje rastlin, medtem ko je baron Erberg, ki je rad sledil sodobnim umetnostnim trendom, v pravilno razporeditev rastlin vključil že bolj modne, nepravilne zaokrožene poti.

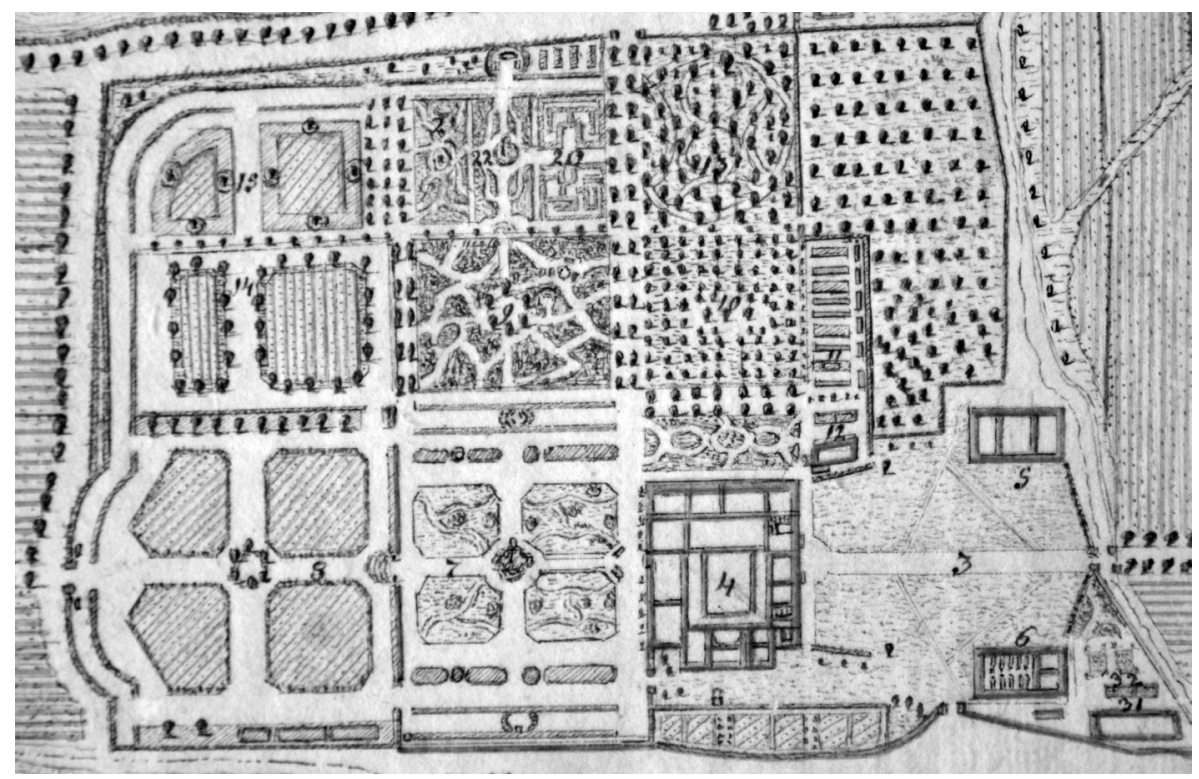

Slika 6: Detajl načrta vrta v Dolu pri Ljubljani, izrisanega leta 1816, kjer je mogoče videti tudi zasnovo Arboreta, označenega s številko 13 (SI AS 207r).

Naj naš prispevek o zbiranju rastlin sklenemo s primerjavo te dejavnosti, kot so jo izvajali v poznem 18. in zgodnjem 19. stoletju ter v prejšnjih stoletjih. Ta primerjava nam pokaže nekaj podobnosti. Zbiratelji so namreč svoje »kabinetno« bogastvo radi popisali in širši javnosti predstavili v katalogih - tako je na primer leta 1584 nastal katalog za naravoslovni kabinet Francesca Calceolarija v Veroni, ki je nakazoval uporabnost kabineta in njegovo povezavo $\mathrm{z}$ delom Calceolarija, lastnika ene najslavnejših lekarn v mestu. V 18. oz. 19. stoletju so prav tako nastajali katalogi, ki pa so ponazarjali le določen del botaničnega bogastva lastnika - najsibo katalog kraljeve botanične zbirke ali katalog pelargonij barona Erberga na Kranjskem (Olmi, 1986, 6; Unetič, 2013, 104, 147). V 16. stoletju je postala navada tudi primerjanje kabinetnih

25 Arboret v dolskem vrtu je označen tudi kot Botanischer Platz (SI AS 730, fasc. 25, fol. 256, 366; SI AS 730, fasc. 5, fol. 947, 952). Za natančnejši prikaz celotnega vrta glej: Unetič, 2013, 246-257. 
raritet in novih, z njimi povezanih znanj med zbiralci, navada, ki se je v poznem 18 . in 19. stoletju nadaljevala, kot je mogoče videti v primeru Erbergove korespondence (Impey, MacGregor, 1986, 2; Unetič, 2013). Prav tako je bila za zbiratelje pomembna slava, ki so jo s svojimi raritetami lahko pridobili. K temu je v 17. stoletju stremel na primer Manfredo Settala, ki je v svojem kabinetu v Milanu zbiral naravne artefakte, etnografske dokumente, znanstvene inštrumente, knjige, antikvitete in umetniška dela. S svojo zbirko je privabljal gospe in gospode, ki so potovali iz Anglije, Francije ali Nemčije v Italijo, njegov glavni cilj (kot tudi pri drugih sočasnih zbirateljih) pa je bil voditi kronane glave ali vsaj pomembne kraljeve sorodnike po svojem kabinetu. Njegova promocija lastne zbirke je bila uspešna, saj je moral na stara leta zaradi številnih obiskovalcev poslati služabnike, da so vodili gospodo, sam pa je vodstvo prevzel le ob obisku pomembnih gostov. Kabineti raritet so v tistih časih lahko nudili pomembno vrzel in priložnost napredovanja v rigidni socialni hierarhiji (Olmi, 1986, 12, 13). Podobno se je godilo na Kranjskem leta 1821, ko je v Ljubljani potekal kongres svete alianse. Ob tej priložnosti je namreč cesarski par obiskal barona Erberga in dolski vrt (vzrok za njun obisk je mogoče iskati v službovanju barona na Dunaju ter skupnem zanimanju za rastline). Baronu je torej uspelo voditi po svojem parku zelo pomembne goste. V počastitev obiska cesarja Franca II. in njegove žene je dal postaviti empirski spomenik, leta 1822 pa je uredil še nov predel v vrtu, kamor je umestil spomenik. ${ }^{26}$

Ob primerjanju naravoslovnih kabinetov raritet in delov zasebnih vrtov, ki so imeli poudarjeno botanično vsebino, opazimo tudi razlike. Najdemo jih lahko v razporeditvi artefaktov ali rastlinskih vrst. Kabineti poznega 16. in 17. stoletja so navadno sledili matematičnim pravilom in tradicionalni predstavi estetike, torej simetriji in čim bolj pravilni razporeditvi (Olmi, 1986, 9), medtem ko postanejo v »botaničnih« vrtovih poznega 18. stoletja kriteriji za razporeditev vrsta rastline, njena obstojnost v danih klimatskih razmerah, rastne značilnosti in razmere ipd. Kot smo lahko videli na primeru Brda pri Kranju in Dola pri Ljubljani, vrtne zasnove teh delov vrtov niso bile enotne - lahko so bile pravilne ali pa so se v njih že znašle zaobljene linije. Naslednjo razliko lahko najdemo v cenah artefaktov, ki se v poznem 18. in zgodnjem 19. stoletju navadno ne povzpnejo tako visoko, kot se je lahko zgodilo pri čebulici tulipana. Gotovo so posamezniki odšteli velike vsote za redke in odrasle primerke, a so jih lahko dobili v zameno za drugo rastlino ali v določenih okoliščinah celo za manjše plačilo. Tak primer najdemo pri baronu Erbergu, ki je iz Ljubljane, natančneje, iz prodanih Zoisovih vrtov jeseni 1817 in spomladi 1818 v Dol odpeljal večje število rastlin, predvsem dreves. Avgusta 1817 je namreč Žiga Zois sklenil dogovor s kupcem njegovih vrtov in baronom

26 Podobno se je na obisk kronane glave odzval Rihard Ursini grof Blagaj. 14. maja 1838 ga je v Polhovem Gradcu obiskal saški kralj Friderik August, da si ogleda novo botanično odkritje - Blagajev volčin (torej avtohtono rastlinsko vrsto). V spomin na ta dogodek je dal grof še isto leto ob vznožju bližnjega hriba postaviti spomenik (Unetič, 2013, 88, 183, 253, 345 s tam navedeno literaturo). 
Erbergom, da lahko ta za 100 goldinarjev ${ }^{27}$ odkupi eksotično rastje $e^{28}$ njegovega vrta, ga izkoplje in do konca marca prihodnjega leta odpelje v Dol (Unetič, 2013, 91). Kot tretjo razliko bi lahko navedli vrstni obseg naravoslovnih oz. botaničnih kabinetov. Ti so v 16. in 17. stoletju ponazarjali univerzum ali celo idejo izgubljenega raja - dokler zbiranje vseh znanih in novoodkritih rastlin ni postalo preobsežno. V poznem 18. in 19. stoletju pa se je zbirka rastlin omejila predvsem na tiste, ki so bile tedaj v modi naj so bile to pelargonije in njihovi križanci, agave, ki so bile nekaj posebnega zaradi svojega cvetenja, ali rastline iz oddaljenih južnoafriških ali azijskih krajev. Vsa Evropa je sledila splošnemu trendu, ki je narekoval priljubljenost rastlin. Poleg manjšega obsega rastlinskih vrst, njihove dostopnejše cene ter načina razporeditve rastlin oz. artefaktov je »botanične« vrtove 18. in 19. stoletja od naravoslovnih kabinetov 16. in 17. stoletja razlikoval tudi družbeno pogojen in spremenjen odnos do rastlin oz. zbiranja botaničnih zakladov.

Odnos posameznikov do rastlin je bil torej v 16. in 18. stoletju drugačen. Ta sprememba je bila posledica razsvetljenstva, ki je poseglo v vse sfere človekovega delovanja in spremenilo družbene prioritete, vrednote, dojemanje itn. Lastniki "preobraženih « naravoslovnih kabinetov oz. botaničnih delov vrtov so imeli do rastlin drugačen odnos zaradi razvoja botanike kot znanstvene vede, pomena ekonomije lastnih posesti, razvijajočega se izobraževanja in spremenjenega dojemanja narave.

Če v 16. in 17. stoletju zbiratelj rastlin ni bil nujno strokovno podkovan v naravoslovnih znanjih, je strokovnost (tudi samoiniciativna) v 18. stoletju postala sestavni del zbiranja. Na Kranjskem je to dobro vidno v primeru botanika Karla Zoisa, ki je odkril nekaj novih vrst in zbiral slovenska oz. kranjska imena rastlin, ali Jožefa Erberga, ki je z beležko spremljal rast tujih vrst v svojih rastlinjakih (Unetič, 2013, 81-82, 90). S tem je povezano tudi dejstvo, da se je v drugi polovici 18. stoletja pospešeno razvijalo izobraževanje $-\mathrm{v}$ tem času se izoblikuje pedagogika. Izobraževalno funkcijo botaničnih vrtov smo omenili že pri Zoisovih ljubljanskih vrtovih in Erbergovem Arboretu. V severnonemškem prostoru pa je ta povezava še bolj jasno vidna $\mathrm{v}$ ustanovitvi izobraževalne ustanove za mlade plemiče (zemljiške gospode), ki so se v Schnepfenthalu učili obdelovanja zemlje, prepoznavanja vrst, opazovanja narave idr. $\mathrm{Na}$ ta način so pridobivali zavest in odgovornost do okolja, v katerem so kasneje delovali (Düselder, 2008, 33-38). Prav upravljanje posesti oz. njegova ekonomija je bila pomemben dejavnik pri plemstvu, da se je zanimalo

27 Postavljena cena je precej nizka, saj je cena sadike nekega neavtohtonega drevesa (npr. Acer negundo) tedaj znašala okoli 20 goldinarjev. Vemo, da je baron Erberg prepeljal več odraslih tujerodnih dreves, ki bi jih lahko vsako posebej ovrednotili vsaj na 50 goldinarjev.

28 Med drevesi so bili tulipanovec, ginko in 27-letna velikocvetna magnolija. Magnolijo si je ob obisku ogledal tudi cesar, saj je bila edini, na prostem rastoči primerek svoje vrste v celotni monarhiji (Vardjan, 1994, 19; Unetič, 2013, 91, 128). 
za nove in tuje rastline. $\mathrm{Z}$ novimi vrstami je zemljiška gospoda namreč lahko povečala produktivnost lastnega gospostva, donosnost gozda in količino pridelka ter izboljšala raznolikost lastnega jedilnika (Düselder, 2008, 42, 45). Novo znanje je prineslo tudi nastanek drevesnic (die Baumschulen), ki bi jih našli tudi v Dolu pri Ljubljani. Prav v drevesnici v Dolu so leta 1822 kupili kostanje, ki so jih zasadili v Tivoliju in tako dopolnili tedanji Lattermannov drevored (Unetič, 2013, $300 \mathrm{~s} \mathrm{tam}$ navedeno literaturo). Izkaže se, da je bilo botanično znanje za zemljiške gospode nujno potrebno za njihovo konkurenčnost na gospodarskem trgu. Vsekakor pa botanični deli vrtov niso nudili le koristi, ampak so vrtove tudi estetsko dopolnjevali. Kot nekakšni razstavni prostori so novim rastlinam omogočali rast, lastnikom in obiskovalcem pa možnost izobraževanja, uživanja v pogledu na nekaj novega in posebnega ter dodaten socialni prostor, kar nakazuje na nadaljevanje baročne tradicije vrtov kot prostorov družabnih prireditev. Kakšno pomembnost je konec 18. stoletja posameznik lahko pripisoval oblikovanim vrtovom z botaničnimi zakladi, nakazuje zapis Edzarda Mauritza zu Inn- und Knyphausen (1748-1824), lastnika posesti Lütetsburg na severozahodu Nemčije in poznavalca rastlin, ki je podobno kot Erberg - vodil živahno korespondenco s sopoznavalci oz. ljubitelji. Edzard Mauritz namreč leta 1796 zapiše, da je na svojem posestvu uredil krajinski vrt (katerega sestavni del so morale biti tudi tuje in nove rastlinske vrste), ker je želel ustvariti prijetno okolje zase, za svojo družino in potomce; želel si je namreč, da urejena okolica deluje spodbudno na (trenutnega in prihodnjega) lastnika, da $\mathrm{mu}$ bo upravljanje posesti $\mathrm{v}$ veselje - veselje, ki ga drugi iščejo v prekomernem zapravljanju, igrah (na srečo) ali dragih potovanjih, kar lahko družino vodi v pogubo (Düselder, 2008, 31, 40-41). K temu lahko dodamo, da so predvsem plemiči v aktivnem delovanju na področju botanike videli lasten prispevek $\mathrm{k}$ dobrobiti države in možnost sodelovanja z njo (Düselder, 2008, 20). Na ta način se torej zrcali tudi nacionalna zavest in podpora vladajočim, kar lahko prepoznamo tudi v delovanju barona Erberga na Kranjskem.

Botanični vrtovi poznega 18 . in zgodnjega 19. stoletja so kazalci zatona nekdanjih naravoslovnih kabinetov raritet in preobrazbe dejavnosti zbiranja rastlin. Čeprav lahko ob primerjavi kabinetnih naravoslovnih zbirk in »botaničnih vrtov« zgodnjega 19. stoletja najdemo podobnosti npr. v popisih oz. katalogih botaničnih zbirk, v izmenjavi znanj med zbiratelji in ljubitelji ter v pomembnosti pridobljenega slovesa zbirke, ki je lahko nudil možnost premostitve neenakosti družbenih slojev, so tu tudi številne razlike. Spremeni se namreč način prezentacije, ki je od poznega 18. stoletja sledil novim znanstvenim spoznanjem, cene botaničnih primerkov ne dosegajo več vratolomnih višin kot nekdaj, prav tako se spremeni obseg zbirk, ki od poznega 18. stoletja ne sledi več ideji poustvarjanja izgubljenega 
raja, ampak postavlja v ospredje modne vrste. Pomembne spremembe prinese tudi nova družbena miselnost. Ta poudarja strokovnost in znanstvenost, v oblikovane vrtove vnaša funkcijo izobraževanja in se - predvsem $v$ primeru plemiških vrtov - poglobljeno ukvarja tudi z ekonomskim učinkom novih rastlin in izboljšanjem gospodarskega donosa posesti. Spremeni se estetsko dojemanje rastlin, ki (še vedno kot del narave) postanejo samozadostne in kot naravna krajina posamezniku nudijo doživljajski prostor. Poleg tega so v tem času oblikovani vrt - torej tudi njegov botanični del - razumeli kot socialni prostor, tj. predvsem prostor, kjer družina preživlja skupni prosti čas, hkrati pa lahko $\mathrm{v}$ urejanju in stalnem dopolnjevanju repertoarja botaničnih bogastev botaničnih delov vrtov prepoznamo težnjo lastnika, da se približa vladajočim, ki so s svojo dvorno dejavnostjo na področju zbiranja rastlin ponujali vzor - s sledenjem temu vzoru pa je posameznik izkazoval tudi svojo pripadnost vladavini oz. državi.

V preobrazbo zbiranja rastlin je bilo torej vključenih več dejavnikov - ne zgolj radovednost posameznika ali kolonialna težnja, ki izhaja še iz starega veka, ampak tudi novo razumevanje narave, družine, družbe, države, znanja in ekonomije, ki je v tem času ustvarilo pravo »botanizirajočo« javnost, katere del so bili vladarji, duhovniki, plemiči, intelektualci, vrtnarji, tisti, ki so vrt imeli, in tisti, ki ga niso. Vsesplošno navdušenje nad rastlinami, nujno povezano s strokovno (pa čeprav minimalno) podkovanostjo, je prevzelo vso Evropo, tudi Kranjsko, in povezalo ljudi različnih nazorov in slojev - barone, kneze in patre.

\section{Viri}

\section{Arhivski viri}

Arhiv Republike Slovenije (SI AS), Ljubljana:

SI AS 207r, Rokopisna zbirka: Lustall mit seinen Umgebungen in September 1816.

SI AS 730, Graščina Dol (1477-1875):

fasc. 5; Dominicalia: Ein Beitrag ..., fol. 947, 952.

fasc. 20, Dominicalia: Tedenski obračun vrtnarja, fol. 97.

fasc. 23, Dominicalia: Obrtniški računi, fol. 5901; Računi obrtnikov, fol. 5989; Obračun obrtnikov 1828, fol. 6426.

fasc. 25; Dominicalia: Navodila, fol. 256, 366.

fasc. 39, Korespondenca: Dr. Rus, fol. 68.

fasc. 43, Korespondenca: Erberg - Gruber.

fasc. 55, Korespondenca: Walser, fol. 588; Webern, fol. 697; Wohinz, fol. 812. 
fasc. 63, Korespondenca: Erberg Betty.

fasc. 75, Posebno udejstvovanje: Zois - Erberg, fol. 1039, 1061.

fasc. 76, Posebno udejstvovanje: seznam risb.

Narodna in univerzitetna knjižnica (NUK), Ljubljana:

NUK 11236 - Medicus 1783: Medicus, F. K., Beiträge zur schönen Gartenkunst zweite Auflage, Mannheim 1783.

\section{Literatura}

Amrhein, A., Neo-Assyrian Gardens. A Spectrum of Artificiality, Sacrality and Accessibility, Studies in the History of Gardens \& Designed Landscapes 35/2, 2015, str. 91-114.

Bartha-Pichler, B. in drugi, Teufelsfeige und Witwenblume, Christoph Merian Verlag 2010, str. 100-101, 108.

Bauer, G., Nachricht über eine im Sommer 1832 in Blüte gestandene Agave americana in dem Garten zu Lustthal bei Laibach in Krain, Gartenzeitung, XI/34, 25. avgust 1833, str. $265-268$.

Baumgartner, T., Anmerkungen zur Baugeschichte der Eisenstadter Orangerie, v: Der Natur und Kunst gewidmet - der Esterházysche Schlosspark in Eisenstadt (ur. Prost, F.), Köln, Weimar 2001, str. 153-192.

Bazin, G., DuMont's Geschichte der Gartenbaukunst, Köln 1990, str. 11.

Dash, M., Tulipomania: The Story of the World's Most Coveted Flower and the Extraordinary Passions it Aroused, New York 1999, str. 9, 254-255.

Dobrilovič, M., Začetki uvajanja tujerodnih rastlinskih vrst in njihov vpliv na vrtno oblikovanje na Slovenskem = Introduction of foreign plant species and their influence on garden design in Slovenian lands [magistrsko delo], Ljubljana 2002, str. 56-58, 64.

Dobrilovič, M., The introduction of decorative bulbs in Slovenia = Introdukcija okrasnih čebulnic na slovensko ozemlje, Acta agriculturae Slovenica 93/1, 2009, str. 133-142.

Dobrilovič, M., Kravanja, N., Rastlinsko gradivo prvega botaničnega parka na Slovenskem - Brda pri Kranju, v: Zbornik Biotehniške fakultete Univerze v Ljubljani $81,2,2003$, str. 277-289.

Düselder, H., Vom »Botanisieren« und der »Nützlichkeit der Natur«. Naturaneignung und Herrschaftsverständnis des Adels im Kontext von Kultur, Bildung und Ökonomie, v: Adel und Umwelt (ur. Düselder, H., Weckenbrock, O., Westphal, S.), Köln, Weimar, Dunaj 2008, str. 19-50. 
Ferjan, J. I., pod geslom: Erberg, Allgemeines Künstlerlexikon (knj. 34 / engel-eschini), München, Leipzig 2002, str. 263.

Galavics, G., »Porträts« eines fürstlichen Gartens - Der Esterházysche Schloßpark in Eisenstadt, v: Der Natur und Kunst gewidmet - der Esterházysche Schlosspark in Eisenstadt (ur. Prost, F.), Köln, Weimar 2001, str. 119-151.

Gothein, M. L., Geschichte der Gartenkunst I/II, Hildesheim, New York 1977, str. 415-419.

Heller, T., Agaven (Natur und Tier), Münster 2003, str. 6.

Hunt, J. D., Curiosities to Adorn Cabinets and Gardens, The origins of museums. The cabinet of curiosities in sixteenth- and seventeenth-century Europe (ur. Impey, O., MacGregor, A.), Oxford 1986, str. 1-4.

Impey, O., MacGregor, A. (ur.), The origins of museums. The cabinet of curiosities in sixteenth-and seventeenth-century Europe, Oxford 1986, str. 1-4.

Irish, M., Irish, G., Agaves, Yuccas, and Related Plants, Portland, Cambridge 2000, str. 26, 49-50, 96.

Kolšek, A., Zgodovinski vrtovi v Posavju, v: Zgodovinski vrtovi Dolenjske in Posavja (ur. Kolšek, A., Simič, M.), Novo mesto 2000, str. 45-74.

Kolšek, A., Simič, M. (ur.), Zgodovinski vrtovi Dolenjske in Posavja, Novo mesto 2000, str. 28.

Lack, W. H., Florilegium Imperiale, Botanical Illustrations for Francis I. of Austria, München, Berlin, London, New York 2006, str. 12, 19, 23, 28.

Lenné, v. C., Carolus Linnaeus Johannesu Antoniusu Scopoliju: 1761-1773: posnetki rokopisov pisem s slovenskim in angleškim prevodom = Carolus Linnaeus to Johannes Antonius Scopoli: 1761-1773: photocopies of the manuscripts, Slovene and English translations [v slovenski in angleški jezik prevedla ter spremno besedilo napisala Soban, D., ur. Peterlin, M.], Ljubljana 1995, str. 51, 52.

Mal, J., pod geslom: Breckerfeld Franc Anton, Slovenski biografski leksikon (knj. 1: Abraham - Lužar / ur. Cankar, I., Lukman, F. K. s sodelovanjem uredniškega odbora), Ljubljana 1925-1932, str. 57.

Medicus, F. K., Beiträge zur schönen Gartenkunst zweite Auflage, Mannheim 1783.

Melzer, S., In den Fussstapfen Linnés (Friedrich August der Gerechte von Sachsen und die Botanik), Staatliche Schlösser, Burgen und Gärten Sachsen, Jahrbuch 2007/2008 (Bd. 15), str. 120-129.

Melzer, S., Hortus Regius Pillnitziensis: Frederick Augustus The Just And The Royal Botanical Garden In Pillnitz, v: Designing Botanical Gardens (ur. Robin, N.), vol. 28, št. 3-4, september 2008, str. 351-365. 
Möhring, H. K., Die Topfpflanzenkultur in der Erwerbsgärtnerei, Stuttgart 1952, str. 190.

Mušič, M., Erbergova parkovna kompozicija v Dolu pri Ljubljani, Kronika: časopis za slovensko krajevno zgodovino, IX/2, 1961, str. 93-109.

Olmi, G., Science-Honour-Metaphor. Italian Cabinets of the sixteenth and seventeenth Centuries, The origins of museums. The cabinet of curiosities in sixteenth- and seventeenth-century Europe (ur. Impey, O., MacGregor, A.), Oxford 1986, str. 1-4.

Parsons, G., Aesthetics and nature. London, New York 2008, str. 1-17.

Petkovšek, V., Začetki botanične vede pri Slovencih, Ljubljana 1960, str. 11-23.

Pfundheller, J., Der Blumenkaiser - Oesterreichischen Zeit- und Culturbild, Dunaj 1881, str. 10.

Praprotnik, N., Botanični vrt Karla Zoisa na Brdu, Kronika, 52/2, 2004, str. 167174.

Prost, F. (ur.), Geschichte des Esterházyschen »Hofgartens" in Eisenstadt - Eine zusammenfassende Darstellung, v: Der Natur und Kunst gewidmet - der Esterházysche Schlosspark in Eisenstadt (ur. Prost, F.), Köln, Weimar 2001, str. $35-74$.

Reiter, C., Zierpflanzen, Kleinmachnov 1952, str. 53, 60.

Riedl-Dorn, C., Die Pflanzensammlung des Fürsten Nikolaus II. in Eisenstadt, v: Der Natur und Kunst Gewidmet - Der Esterházysche Schlosspark in Eisenstadt (ur. Prost, F.), Köln, Weimar 2001, str. 193-209.

Rinaldi, B. M., Ein Manifest politischer Autorität. Der Wiederaufbau der Yiheyuan, v: Kunst-Garten-Kultur (ur. Gröning, G., Henneke, S.), Berlin 2010, str. 181196.

Rupprecht, H., Miessner, E., Zierpflanzenbau. Zierpflanzen Von A Bis Z, Berlin 1985, str. 298-299, 305, 395, 499, 500, 502-506.

Scopoli, G. A., Linné, v. C., Joannes A. Scopoli - Carl Linnaeus: dopisovanje = correspondence: 1760-1775 [prevod pisem v slovenski jezik, angleški prevod ter uvodno besedilo Soban, D.], Ljubljana 2004, str. 24-27, 30, 32, 33, 36.

Steffen, A., Handbuch der Marktgärtnerei, Berlin 1940, str. 380.

Symes, M., A Glossary of Garden History, Madison 1993, str. 92-93.

Teichert, O., Geschichte der Ziergärten und der Ziergärtnerei in Deutschland während der Herrschaft des regelmässigen Gartenstyls, Rüsselsheim 1991, str. 201.

Umek, E., Erbergi in Dolski arhiv, Ljubljana 1991, str. 13, 17. 
Unetič, I., Vrtna umetnost na Kranjskem v osemnajstem in devetnajstem stoletju = Garden art in Carniola in the eighteenth and nineteenth century [disertacija], Ljubljana 2013, str. 124-132, 144-146, 233 ss.

Unetič, I., Kranjski razsvetljenci, botanika in oblikovanje vrtov, v: Bilten (Slovensko društvo za preučevanje 18. stoletja) 6, 2014, str. 20-23.

Vardjan, F., Tivolski park od nastanka do danes, v: Tivoli, ljubljanski mestni park (ur. Strgar, J.), Ljubljana 1994, str. 16-38.

Wilkinson, A., The Passion For Pelargoniums - How They Found Their Place In The Garden, Phoenix Mill 2007, str. 13-14, 21-24.

\section{Spletni viri}

Hydrangea macrophylla (Siebold, v. P. F., Zuccarini, G. J., Flora Japonica, Sectio Prima (Tafelband), 1870), https://commons.wikimedia.org/wiki/File:Hydrangea_ macrophylla_SZ53.png [28. 8.2015].

Pelargonium pefltatum (Jan Koninckx, Pelargonium peltatum L., 1701), https:// cs.wikipedia.org/wiki/Pelargonie\#/media/File:Jan_Moninckx08.jpg [28. 8. 2015].

Pelargonium inquinans (Dillenius, J. J. D., Hortus Elthamensis I Tcxxv, 1732), https:// en.wikipedia.org/wiki/File:P_inquinans_Dillenius.jpg [28. 8. 2015].

Primula veris (Thomé, O. W., Flora von Deutschland, Österreich und der Schweiz, Gera 1885), https://commons.wikimedia.org/wiki/File:Illustration_Primula_veris0_ clean.jpg [28. 8. 2015].

Zgodovinski zbornik, 2013 (Zgodovinski Zbornik: Priloga Laibacher Dioecesanblatt-U, London 2013, str. 529-530), http://www.forgottenbooks.com/readbook_text/ Zgodovinski_Zbornik_1500019636/529 [18.9.2015]. 
Ines Unetič

\section{Botanični vrtovi in zbiranje rastlin v luči preobrazbe botaničnih zbirk na Kranjskem v začetku 19. stoletja}

Ključne besede: botanični vrt, zbiranje rastlin, neavtohtone rastline, avtohtone rastline, baron Jožef Erberg, baron Žiga Zois, baron Karl Zois, jezuit Gabriel Gruber

V poznem 18. in zgodnjem 19. stoletju je zbiranje tujih rastlin postalo moda, ki je zajela evropske dvore ter posledično številne plemiče, intelektualce, vrtnarje in druge. Nove rastline so tako gojili v oblikovanih vrtovih, zbirali $\mathrm{v}$ herbarijih in navajali $\mathrm{v}$ katalogih ali jih dajali upodabljati. V tem času ni bilo pomembno le samo zbiranje rastlin, ampak tudi to, da so lastniki oz. zbiratelji pridobili botanično znanje, ki jim je omogočalo, da so te rastline pravilno uporabljali in predstavljali.

$\mathrm{Na}$ Kranjskem bi tovrstno botanično zanimanje prepoznali pri baronu Jožefu Erbergu, baronih Zois, jezuitu Gabrielu Gruberju in mnogih drugih. Aktivnosti barona Erberga, kot jih lahko razberemo iz arhivskih virov (predvsem njegove ohranjene korespondence), so tako vključevale zbiranje rastlin, njihovo izmenjavo in nakup ter zanimanje za druge botanične novosti. Med kranjskimi ljubitelji rastlin so bile posebno priljubljene pelargonije, hortenzije in agave, ki so imele pomembno mesto v oblikovanih vrtovih, pogosto znotraj predela vrta, ki je bil namenjen neavtohtonim rastlinam.

Zbiranje tujih rastlin pa seveda ni le domena obravnavanega časa in prostora, saj so ga poznali že v času starih civilizacij, kot sta bili npr. asirska in kitajska, ter v 16. in 17. stoletju, in sicer v okviru priljubljenih kabinetov kuriozitet. Ob primerjanju slednjih in botaničnih zbirk zgodnjega 19. stoletja lahko prepoznamo nekatere podobnosti (zbiranje redkih, predvsem eksotičnih rastlin ter zbiranje rastlin z namenom prikazati imperialno moč), vendar so družbene spremembe 18 . in 19. stoletja vplivale na botanično zbiranje ter prinesle novosti in razlike. Razvoj botanike kot znanosti, uveljavljanje botaničnega ljubiteljstva, modne rastline, zanimanje za gospodarsko donosnost posesti, spremenjeno dojemanje narave in okolja ter drugih družbenih vrednot, kot sta bili družina in država - vse to je torej okoli leta 1800 vplivalo na priljubljenost zbiranja rastlin v evropskem prostoru oz. na Kranjskem. Tako lahko zbiranje rastlin $\mathrm{v}$ tem času posledično vidimo tudi kot zaton in preobrazbo nekdanjih naravoslovnih kabinetov kuriozitet. 
Ines Unetič

\section{Botanical Gardens and Collecting of Plants in the Light of the Metamorphosis of Botanical Collections in Carniola at the Beginning of the $19^{\text {th }}$ Century}

Keywords: botanical garden, plant collecting, non-indigenous plants, indigenous plants, Baron Joseph Erberg, Baron Žiga Zois, Baron Karl Zois, vicar Gabriel Gruber

In the late $18^{\text {th }}$ and early $19^{\text {th }}$ century, the collecting of exotic plants became a fashion that took hold of European courts, and was followed by many noblemen, intellectuals, gardeners and others. It was not only popular to grow new plants in gardens, collecting them in herbaria or illustrating and enumerating them in catalogues, but was also important to develop botanical knowledge to enable the owners of the plants to use and present them.

In Carniola we can observe this interest in botany in the cases of Baron Joseph Erberg, Barons Žiga and Karl Zois, Jesuit Gabriel Gruber as well as many others. Baron Erberg's activity is recorded in archives which include lively correspondence concerning plant collecting, the exchange and purchase of plants and other botanical matters. So we can see that among plant lovers in Carniola foreign plants such as pelargonium, agave and hydrangea were popular and that they had a special role in gardens devoted especially to exotic plants.

The collecting of exotic plants is not just a phenomenon of the eighteenth and nineteenth centuries but can be traced back to early civilisations such the Assyrians and ancient Chinese and was also notable in a the $16^{\text {th }}$ and $17^{\text {th }}$ centuries with their cabinets of curiosities. But studying the botanical collection of exotic and new (or newly defined) plants gardens of the late $18^{\text {th }}$ and early $19^{\text {th }}$ centuries shows us that although we can recognize some of the old "habits" in the process of collecting (collecting of rare, fascinating plants or collecting plants to demonstrate imperial power) the social changes in the $18^{\text {th }}$ century left their trace also in this aspect of human activity. Thus we can understand plant collecting of this time as a decline and metamorphosis of the former natural cabinets of curiosities. In botanical gardens of the late $18^{\text {th }}$ and early $19^{\text {th }}$ century we see the development of science of botany, the rise of the amateur botanist, a different perception of nature and the environment, the development of education and new social values including family and state, which all had an impact on the popularity of the plant collecting around the year 1800 in Europe and in Carniola. 